\title{
AGRICULTURE VS. SOCIAL SCIENCES: SUBJECT CLASSIFICA- TION AND SOCIOLOGICAL CONCEPTUALIZATION OF RURAL TOURISM IN SCOPUS AND WEB OF SCIENCE
}

\author{
Marjan HOČEVAR ${ }^{1}$, Tomaž BARTOL ${ }^{2}$
}

Received June 29, 2016; accepted August 28, 2016.

Delo je prispelo 29. junij 2016, sprejeto 28. avgusta 2016.
Agriculture vs. social sciences: subject classification and sociological conceptualization of rural tourism in Scopus and Web of Science

Agriculture and consumptive function of countryside (rural areas) are connected which should be reflected in scientific research. In order to test relationships, we selected the topic of rural tourism (also agritourism, agrotourism, agricultural tourism) considering sociological conceptualization (social sciences, sociology) and methodological approaches of information sciences (bibliometrics, scientometrics) in describing fields of science or scientific disciplines. We ascertained scatter of information in citation databases (Web of Science, Scopus, Google Scholar). Functionalities were evaluated, affecting search precision and recall in information retrieval. We mapped documents to Scopus subject areas as well as Web of Science (WOS) research areas and subject categories, and related publications (journals). Databases do not differ substantially in mapping this topic. Social sciences (including economics or business) occupy by far the most important place. The strongest concentration was found in tourism-related journals (consistent with power laws). Agriculture-related publications are rare, accounting for some $10 \%$ of documents. Interdisciplinarity seems to be weak. Results point to poor inclusion of emerging social topics in agricultural research whereby agriculture may lose out in possible venues of future research.

Key words: rural tourism; social sciences; agricultural sciences; science mapping; classification; interdisciplinary research; citation databases; sociological conceptualization
Kmetijske in družbene vede: predmetna klasifikacija in sociološka konceptualizacija podeželskega turizma v zbirkah Scopus in Web of Science

Kmetijstvo in konzumptivna funkcija podeželja (podeželska območja) sta povezana, kar naj bi se odražalo tudi v znanstvenem raziskovanju. Da bi preverili razmerja, smo izbrali predmet podeželskega turizma (tudi kmečki turizem, agroturizem, agriturizem), upoštevajoč sociološko konceptualizacijo (družbene vede, sociologija) ter metodološke pristope informacijskih znanosti (bibliometrija, scientometrija) pri opisovanju znanstvenih področij oz. znanstvenih disciplin. Razkropitev informacij smo raziskovali v citatnih zbirkah (Web of Science, Scopus, Google Učenjak), kjer smo ovrednotili funkcionalnosti zbirk, ki vplivajo na odziv in natančnost pri iskanju informacij. Dokumente smo priredili širšim predmetnim klasifikacijskim kategorijam v zbirkah Scopus in Web of Science, ter ustreznim publikacijam (revijam). Zbirki se pri kartiranju oz. klasificiranju te tematike bistveno ne razlikujeta. Družbene vede (vključujoč ekonomiko) zasedajo daleč najbolj pomembno mesto. Največjo koncentracijo je najti pri turističnih revijah (v skladu s potenčnimi zakoni). Publikacije s področja kmetijstva so redke (kakih $10 \%$ ). Interdisciplinarnost se izkazuje dokaj šibko. Rezultati kažejo, da raziskave s področja kmetijstva le redko zajemajo novejše družbene tematike, zaradi česar bi kmetijstvo lahko zamudilo pri vključevanju v nekatere možne smeri prihodnjih raziskav.

Ključne besede: podeželski turizem; družbene vede; kmetijske vede; kartiranje znanosti; klasifikacija; interdisciplinarne raziskave; indeksi citiranja; podatkovne zbirke; sociološka konceptualizacija

1 Univ. of Ljubljana, Fac. of Social Sciences, Dept. of Sociology, Kardeljeva pl. 5, SI-1000 Ljubljana, Slovenia, e-mail: marjan.hocevar@fdv.uni-lj.si

2 Univ. of Ljubljana, Biotechnical Fac., Dept. of Agronomy, Jamnikarjeva 101, SI-1000 Ljubljana, e-mail: tomaz.bartol@bf.uni-lj.si 


\section{INTRODUCTION}

Agriculture and countryside (rural areas) are generically connected concepts, in a general as well as specialist sense. Agriculture is a productivistic activity contingent on exploitation of (natural) resources and is usually managed in a spatially and socially specific zone: countryside. In agricultural research, countryside represents an instrumentality ("dependent variable"). Agricultural sciences thus rarely focus on non-productional activities in such areas which are then taken on by social sciences. Previously harmonious interdependency of agricultural production and the rural area is changing following a gradual weakening and contraction of the agricultural sector because of demographic, technological, and lifestyle changes, as well as economical structural relations.

Productivist role of the countryside, where agricultural production plays a key role, is increasingly leaning towards the consumption and services, both in terms of land use as well as human resources. In the literature, especially in social sciences, from the 1990s on, the postproductivist and multifunctional transformation of the countryside and the so-called transition in agriculture is strongly present, affirmatively as well as critically (Wilson, 2007; Mackay et al., 2009; Almstedt, 2013). Conceptual and methodological research traditions in the social sciences notwithstanding, the main emphasis is placed on the disclosure of a long-term process which is transforming radically the very comprehension of the concept of agricultural production and rurality (van der Ploeg et al., 2000; Friedland, 2002).

In the policies of the social development as well as in the orientations of the values in population, agriculture is expressed only as one of the (production) activities in rural areas. Self-evident association of the countryside depending (only) on agricultural production in a narrower sense and where such production defines the rural way of life is no longer appropriate (Hočevar, 2012; Uršič and Hočevar, 2007; Mavri and Černič-Istenič, 2014; Schroeder, 2016).

During the last 30 years the significance of nonagricultural activities in rural areas has been growing dramatically (diversification). For example, different residential types can now be found in rural areas. Leisure time is also increasingly spent in rural areas which encourages the development of tourism as a service activity.

We believe that the phenomenon of rural tourism illustrates well the new complex relations between the transitions in agriculture and post-productivistic rurality. Rural tourism can be, to different degrees, indirectly or directly linked to agricultural production, for example, as farm tourism or agro-tourism, but not necessarily so, for example, as rural leisure. Frequently, in such areas, the significance of tourism can be, in the terms of income and employment, even higher than agricultural production itself (Hill, 2005). Here we should note that the concept of rural tourism, in the sense of its relationships with agriculture/farming, is frequently contested. Lacking proper statistics, and capturing and aggregating data in different ways, the researchers interpret such activities differently (Almstedt, 2013).

In some countries, rural tourism plays and integral role in information services for farmers (Moon et al., 2012). Agro-tourism, besides farm tourism in a more narrow sense, covers also other activities. These can also be related to agriculture, food processing, forestry, and similar (Bojnec, 2010). Here, a question arises: how is the significance of rural tourism in rural transformation and subsequent impact on agricultural development policies reflected in scientific research. Many aspects, such as growth of documents, and specific topics, can be verified in information systems and databases, such as Scopus (Lane and Kastenholz, 2015) and the Web of Science. Some research indicates, however, that most research outcomes are presented outside the scope of agriculture, which was evidenced on an example of rural economists and rural sociologists which publish predominantly in social-sciences-related journals De Looze et al. (1996).

Several other articles have tackled rural tourism or tourism in relation to agriculture which will be discussed in the subsequent sections of this paper. The topic of rural tourism was chosen as our model because it is related to both social sciences as well as agriculture and thus exhibits a certain interdisciplinarity and inherent connections between the two disciplines which have already been tentatively explored by Bartol and Hočevar (2011) on the case of the classification of the principal agricultural database CAB Abstracts. Some authors have attempted at a more subjective classification of rural tourism as well as tourism in a more general sense, and not based on Scopus or WOS. Law et al. (2009) identified rural tourism as one of the 12 major topics in tourism. Tian et al. (2011) classified general tourism research topics into 20 categories, including rural tourism. Ruhanen et al. (2015) attempted at delimiting the more specialized topic of sustainable tourism by 16 contextual themes where rural tourism was also itemized. Crouch and Perdue (2015) employed classification system of the Australian Research Council (ARC) and detected growth in the importance of agricultural field in relation to tourism.

Our study employed the proprietary classification schemes of both citation databases thus providing a possibility of repeatability of experiment and comparison with other topics. Namely, literature needs to be organized through consistent classification schemes as these are also used in science policy design and science evalu- 
ation processes (Gómez-Núñez et al., 2014). The insight into the publication practices in scientific disciplines or broader research fields such as agriculture and social sciences thus also has implications in national research evaluation which is in the Slovenian national Current Research Information System (SICRIS) based on links to both Scopus as well as Web of Science (Bartol et al., 2014).

This paper will employ, under the consideration of sociological conceptualization of the subject matter, methodological approaches of information sciences in order to assess the distribution of rural-tourism-related research in citation databases. We will focus on such characteristics, which define analysis of information, for example, the classification of papers, and scatter of papers in different publications (journals) as well as the choice of an appropriate terminology which, based on the review of literature, includes not only the 'generic' concept of rural tourism but also some associated terms which can in a document title convey a very similar meaning. Selected functionalities of both citation databases will also be assessed as these may have an effect on information retrieval. We expect to detect a steady growth of possibly relevant documents due to an increasing socio-economic importance of rural tourism. Despite the interdisciplinary nature of this topic we expect to find more documents in social-sciences-related publications and applicable classification categories than in agricultural publications and categories. Here, we will also try to ascertain these distributions more exactly.

\section{MATERIALS AND METHODS}

\subsection{SELECTION OF DATABASES}

We have included both principal international citation databases Scopus (Elsevier) and the Web of Science (Thomson Reuters; henceforward referred to as WOS) covering the entire period up until the end of 2015 even though the timeline of coverage in both databases is different. Namely, the growth has been more pronounced only after 2005. In Scopus, we used the regular database which is available on a customary subscription basis. WOS has recently begun to include other information products, which are not included in the JCR metrics (Journal of Citation Reports and the subsequent Impact Factor). We have employed the central product 'Web of Science Core Collection' which in our subscription plan (as of spring 2016) also includes the products such as Conference Proceedings Citation Index and Book Citation Index besides the more journal-oriented products Science Citation Index Expanded (SCI-Expanded), So- cial Sciences Citation Index and Arts \& Humanities Citation Index (A\&HCI). As Scopus regularly includes proceedings series the augmented WOS version now offers a possibility for a more balanced comparison of both databases. At this point it needs to be emphasized that both citation databases constantly update and expand their coverage and revise functionalities and analytics, thus, any similar assessment is only valid at the period of analysis. We also employed Google Scholar on a limited example of search terms in order to provide some insight into the dispersal of information outside the more restricted scope of journal-centered citation databases.

\subsection{CHOICE OF SEARCH TERMS}

Based on the estimation of the sociological relevance of this concept and review of applicable literature we designed different queries and ran test searches. For example, Hassan et al. (2014) used the term 'rural tourism' as one of the essential keywords for the concept of rural development in a study which identified sub-areas of sustainable development. 'Agriculture' was also identified as one of the core keywords of the subject area of 'Tourism industries and tourism attractions' by (Wu et al., 2012). Philip et al., (2009) presented an overview of the terms, where it becomes evident that Agritourism, Farm Tourism, Farm-based tourism, Agrotourism, and even Vacation Farms describe various aspects of rural tourism which are almost freely interchangeable.

The comparison of both databases can only be conducted through document-title searches. In both databases, there exist the so called topical fields which include article title and abstract, as well as different keyword fields. Keywords in both databases are mapped to articles on fairly different principles. Besides the authorkeywords, additional keywords are in WOS also extracted from the references (Keywords Plus). In Scopus, they are extracted from different thesauri, which are different in different records.

Thus, for the purposes of consistency we compared the occurrences of search terms only in the titles. In Google Scholar, the only option is to use either the titles or the entire document's full-text along with the accompanying bibliographic descriptions which produces too much retrieval noise. Search precision with the term rural tourism would be high, however, many possibly relevant documents would have been lost so we expanded the query to include some other applicable terms. The required search term (right truncated word stem or fragment) in our query was touris ${ }^{*}$. It returns the concepts such as tourism, tourist(s), touristic. The terms agric ${ }^{*}$, rural, farm $^{\star}$ were selected as optional search terms and 
were required to occur along with touris ${ }^{*}$. Truncated $a g r^{\star}$ would not be appropriate as it produces too much noise, for example 'tourist agreements'. In addition, we have included some compound terms which usually occur in documents originating from specific national contexts (agritouris ${ }^{*}$, "agri touris ${ }^{\star ", ~ a g r o t o u r i s ~}{ }^{*}$, "agro touris ${ }^{* ”)}$. Namely, national terminologies are conditioned by culture-dependent designation of a phenomenon (Nielsen et al., 2012; Fijo-León and Fuentes-Luque, 2013; Yozukmas et al., 2014). This can also be an outcome of legislation. For example, in Italy agritourism is considered an agricultural activity and can only be performed by a farmer. Moreover, Italian national legislation forces farmers to dedicate their activities mainly to traditional farming, rather than to tourism activities (Mastronardi et al., 2015).

Search terms employed in the research:

\section{1 required search term: \\ 1.2 optional search terms: \\ 2 additional terms:}

touris ${ }^{\star}$

agric $^{*}$ or rural or farm $^{*}$

agritouris $^{*}$ or agrotouris ${ }^{\star}$ or "agri touris" or "agro touris ${ }^{\star ”}$

Combined search query for the use in both databases based on the above index:

((touris ${ }^{\star}$ and $\left(\right.$ agric $^{*}$ or rural or farm $\left.\left.{ }^{\star}\right)\right)$ or agritouris ${ }^{\star}$ or agrotouris ${ }^{\star}$ or "agri touris ${ }^{\star ”}$ or "agro touris ${ }^{\star ")}$.

At this point it needs to be explained that there exist many other terms which are potentially associated with agriculture, farms and tourism, such as leisure, holidays, pastime, recreation, sport, travel, which can all be related

Table 1: Occurrences of compound terms and fixed phrases according to title-terms in Google Scholar, Scopus and WOS until the end of 2015

Preglednica 1: Pojavnost sestavljenih izrazov in fraz $v$ naslovih dokumentov v zbirkah Google Scholar, Scopus in WOS do konca 2015

\begin{tabular}{lllc}
\hline Title terms & Google Scholar & Scopus & WOS \\
\hline "rural tourism" & 4420 & 512 & 353 \\
intitle:agritourism & 548 & 103 & 64 \\
intitle:"agrotourism" & 284 & 22 & 19 \\
intitle:"agro tourism" & 212 & 24 & 22 \\
intitle:"farm tourism" & 205 & 39 & 19 \\
intitle:"agricultural tourism" & 182 & 13 & 8 \\
intitle:"agri tourism" & 125 & 11 & 6 \\
\hline
\end{tabular}

to countryside (rural areas) services and consumptive activities. Such terms, however, return too many results outside the immediate scope of our research.

As an additional information we provide a simple table of the occurrences for the compound terms and fixed phrases according to title-terms in Google Scholar (excluding patents and citations), Scopus and WOS up until the end of 2015 (Table 1).

Table 1 shows that the title phrase rural tourism occurs most frequently in all information systems, followed by agritourism. Agritourism as a term is frequent in Mediterranean Europe, especially in Italy and is very similar to the more 'British' concept of farm tourism (Manca 2008). It also comes about in Spanish context. The review of literature reveals that agrotourism is frequently used in some countries of the Central and Eastern Europe. Needless to say, as in most topics, social, cultural and linguistic particularities of a term-usage are very important and can influence search precision as well as recall of information. They should be heeded in any analysis based on specific terminology and information retrieval which is, however, not always the case.

Considerable difference between Google Scholar and both citation databases in the coverage of tourism is in vast contrast with the more 'agricultural' topics which do not exhibit so pronounced a lead in Google Scholar (Bartol and Mackiewicz-Talarczyk 2015). The importance of Google Scholar in the coverage of tourism was noted by Hall (2011). Namely, Scholar provides information on many other types of documents other then journal articles. However, our combined complex search query could not be replicated on Google Scholar as this information system offers no possibility of truncated searching. Some stemming (lemmatization) is sometimes employed on Google Scholar instead of truncation (typically with an asterisk). This functionality, however, is not consistent and cannot be relied upon in retrieval.

\subsection{SCOPUS AND WOS ANALYTICS AND RANK- ING}

Both databases provide possibilities for mapping, clustering, and ranking of documents, and subsequent analysis, according to several selected bibliographic elements, for example: authors, countries, source titles, subjects, years etc. In our experiment, we have assessed the yearly growth of records, broader mapping of publications to subject areas, research areas and categories as well as principal publications. Whereas some elements are fairly self-explaining, the classification according to the Scopus Subject areas, as well as WOS Research areas 
and WOS categories needs some methodological explanation.

Both databases provide a possibility for mapping and clustering of documents on a basis of broader subjects. This classification is in both systems based on the assigning of one or several subject classes to the entire publication (usually journal) in which a particular paper has been published. These are proprietary schemes and differ substantially, even for the same document, in both databases. In Scopus, the broad classification is based on 27 major subject areas. There also exist several hundred minor subject areas. Subject analytics of Scopus search results (the database function: "Analyze search results") is conducted on subject areas: Analyze Search results -> Subject area. Minor subjects (Subject Categories) can be ascertained separately through other Scopus-related products (e.g. Scimago). In WOS, the broader subject analytics (the database function: "Analyze results") can be conducted on some 150 research areas and some 250 subject categories: Analyze Results -> Research Areas; Analyze Results -> Web of Science Categories. These can also be mapped, roughly, to Frascati OECD Field of Science and Technology (FOS) classification. Journal titles may belong to more than one subject category or subject area in both databases.

Such classification is especially relevant in the journal metrics of both databases. In WOS, they serve for the assessment and ranking of journals in the Journal Citation Reports, and the subsequent Impact Factor (IF). In Scopus, they are used in in the Source Normalized Impact per Paper (SNIP), and Scimago Journal Rank (SJR). However, these classes are also assigned to almost all other documents such as proceedings papers and book chapters. In our analysis, we have thus retrieved and analyzed all papers regardless of the document type.

\section{RESULTS AND DISCUSSION}

\subsection{YEARLY PROGRESS OF RECORDS}

The study has identified 1260 records in Scopus and 820 records in WOS based on title- term model query:

$\left(\left(\right.\right.$ touris $^{\star}$ and $\left(\right.$ agric $^{\star}$ or rural or farm $\left.\left.{ }^{*}\right)\right)$ or agritouris ${ }^{\star}$ or agrotouris ${ }^{*}$ or "agri touris*" or "agro touris ${ }^{\star *)}$.

The model query (referred to as all terms in Fig. 1) was presentedin the subsection 2.2. It included all records published in the entire period up to the end of 2015. Figure 1 presents all records between 1990 and 2015. Before this period, only a few documents were published each year, and in some years none. As expected and substantiated in other studies (Lane and Kastenholz,

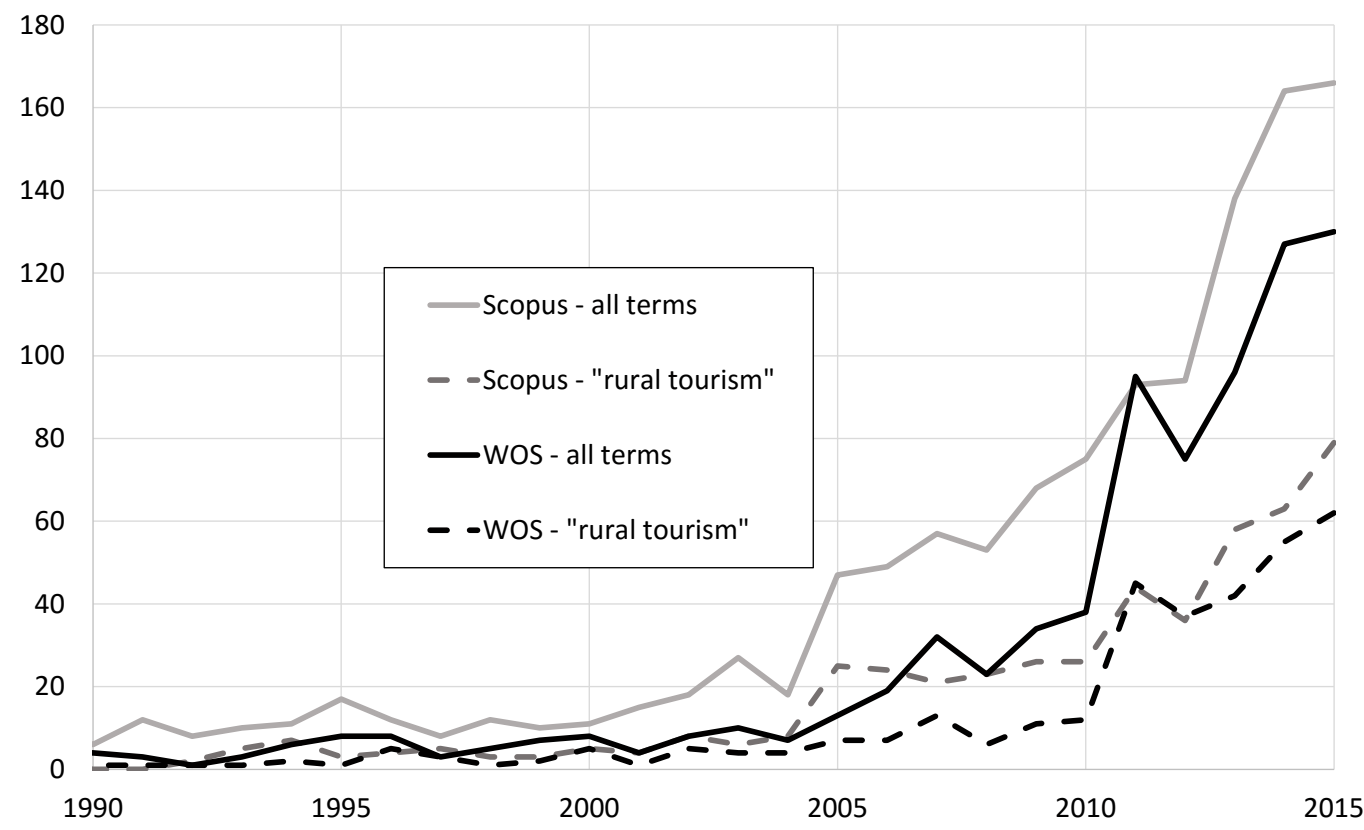

Figure 1: Growth of records (1990-2015) in Scopus and Web of Science (WOS) retrieved with article title terms (all terms: expanded query; "rural tourism": simple query -this exact phrase only)

Slika 1: Rast zapisov (1990-2015) v zbirkah Scopus in WOS, ki jih prikliče iskanje po naslovih dokumentov (all terms: razširjena poizvedba; "rural tourism": enostavna poizvedba - le ta natančna fraza) 
2015), the documents in this field are growing constantly. This growth is more pronounced only after 2005. A local 'peak' can be observed, for example, in 2011 in WOS. This can be attributed to a single title-item in a book series dedicated to tourism and agriculture. This book was not indexed by Scopus.

The additional simple query was based only on the exact phrase rural tourism. We can observe that this phrase accounts for almost $50 \%$ of all records in each year. The other half can be attributed to the occurrences of the expanded-query terms in different contexts. This reflects the complexity and differentiation of the studied topics. Bellow, we present some examples of these occurrences in document titles:

\section{... tourism planning in rural areas ...}

... sustainable development of eco-agricultural tourism ...

... tourism ... spaces in sustainable agriculture

... research on the development of the farm tourism in ...

... tourism-based leisure farms

... farming tourism, a social approximation of ecology ...

... heritage tourism ... rural community

... influence of agritourism ...

... agri-tourism's contribution to ... economy

... importance of agrotourism for sustainable economic development ...

... history of agro-tourism in ...

The examples of the above title concepts are all based on tourism. However, many articles also employ terms such as tourist, tourists:

... tourist use of traditional rural buildings

... agriculture and the rise of the tourist industry

... tourist family farms

... tourist choice of leisure farming types ...

... targeting rural tourists in the internet...

As argued previously, different terms could convey similar meanings. Also, different terms can reflect different search intentions and thus define subsequent published outcomes. For example, instead of tourists the term visitors could also be used. However, such term may possess several other connotations which do not relate essentially to tourism. For example, in case of outbreaks of diseases: 'Escherichia coli ... rural residents and visitors in livestock farming areas', '.... colitis in child after visit to farm'. On the other hand, a couple of articles bring 'inverse' contexts, such as are related to the negative impact of tourism: '... impact of tourism on agriculture .... Such articles are not necessarily related to rural tourism in a more strict sense even though some links do exist. A few lone articles relate to the concepts such as 'fish farms' or 'wind farms' with regard to the impact on tourism. Such documents, however, are very rare. Search noise of this type can only be identified 'manually' by verifying the context of each document.

\subsection{SCOPUS SUBJECT AREAS AND WOS RE- SEARCH AREAS AND SUBJECT CATEGORIES}

Classifications show how many documents were published in publications mapped to different subject classes according to database-specific analytics. In Scopus (Fig. 2), 661 documents were classified as pertaining to Social sciences, among the total of 1260 documents, followed by Business, management, and accounting. Agricultural and biological sciences come about only on the sixth place with 143 documents. Altogether, the articles relating to rural tourism were published in publications mapped to 25 different subject areas where some of them account for just a few articles. Whereas both articles in the Physics and astronomy are applicable (...rural tourism spatial distribution ... GIS ...), the lone article mapped to Health professions is not. In Scopus, nonEnglish document titles may come about, side-by-side, in two languages: the original and English translation. In this case, the Spanish version of a document title involves the word farmacia which has been duly retrieved via the truncated farm* Such instances are difficult to exclude systematically. This shows how important it is to be aware of database characteristics. Scopus thus sometimes yields more noise and, consequently, higher number of non-relevant results. A more restricted search employing, for example, only rural tourism would be more accurate. Such search results, however, would fail to identify many other relevant documents.

In WOS, the 820 records can be analyzed for Research areas (Fig. 3) which represent broader concepts as well as Categories (Fig. 4) which represent narrower concepts. Although the broad Research areas in WOS are more detailed than broad Subject areas in Scopus the former are much more itemized as can be observed comparing Figures 2 and 3. On the broader level, the most important share of documents, in both databases, converge around socials sciences and business-related topics. Regarding the Categories (101 different categories), which are fairly specialized, 318 documents are mapped to Hospitality leisure sport tourism (Fig. 4). The first two 'agricultural' categories are rather slim: Agricultural economics policy (36 documents) and Agriculture multidisciplinary ( 35 documents). As many as 232 records were mapped to 82 fairly specific categories, for example, Social issues (8), Agronomy (8), Architecture (5), Agricultural engineering (4), Cultural studies (3), Nutrition dietetics (2) etc. At this point it needs to be reiterated that records 


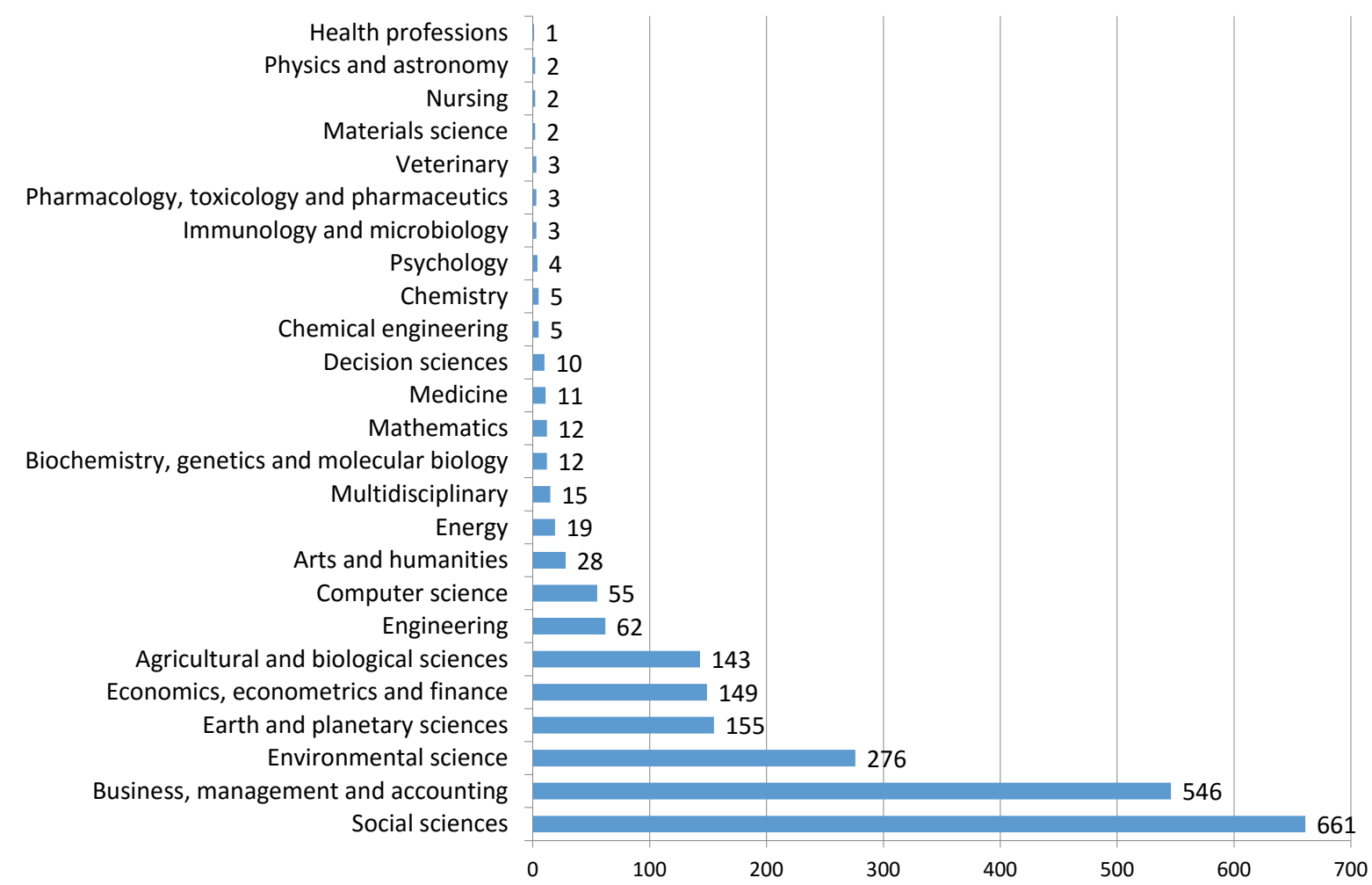

Figure 2: Records in Scopus database retrievable with subject areas and all terms, until the end of 2015

Slika 2: Zapisi v zbirki Scopus, ki so najdljivi s predmetnimi kategorijami in vsemi pojmi, do konca leta 2015

(and respective source publications such as journals) can be mapped to two categories, and sometimes three. Therefore, the numbers in Figures 2, 3, and 4 cannot be counted as a sum of these records.

Figures 2, 3 and 4 show an evident prevalence of social sciences in the classification of publications. In classifications of both information systems, the financial element is also strongly pronounced given its second rank. It seems that different classification schemes and different 'coarseness' or 'graininess' in Scopus and WOS do not play a major role. If we mapped, arbitrarily, all categories (research or subject areas) to the two essential groups, the 'natural/technological' sciences (all life sciences, medicine, technologies and engineering ...) on one hand and social sciences (incl. economics, humanities) on the other, the prevalence of the latter would be even more evident. Mapping also shows that rurality and tourism are natural explorative 'strongholds' in social sciences therefore agriculture is in such research frameworks contextual ('dependent variable'). Even in the case of a possibly interdisciplinary research such documents are most probably published in and mapped to social-sciences-related publications and subsequent categories. We assume that this epistemological issue can be attributed to seeming or factual discrepancies of research styles and approaches in addressing agriculture and rural areas. Namely, social sciences prefer qualitative (interpretative) methods whereas life sciences, including agriculture, favor quantitative procedures. Researchers in different disciplines may study the same phenomenon but differ in their theories or explanatory models (and underlying assumptions) (Lélé and Norgaard, 2005; Nujiten, 2011).

\subsection{PRINCIPAL PUBLICATIONS}

Table 2 presents those publications in both databases which published at least 10 papers referring to rural tourism and related terms in paper titles. The numbers in italics present those items which are fewer than 10 . Some publications are indexed by both databases, coverage of articles per publication, however, are different. Most WOS-indexed journals are also referenced in Scopus. Contrary is not always the case. On the other hand, the expanded version of the new WOS Core Collection now also includes proceedings (further down the list in Table 2) which are not included in Scopus. This is the situation as of 2016. Both databases are constantly expanding their coverage by including new publications, also such as may had been published years ago. Also, it is 


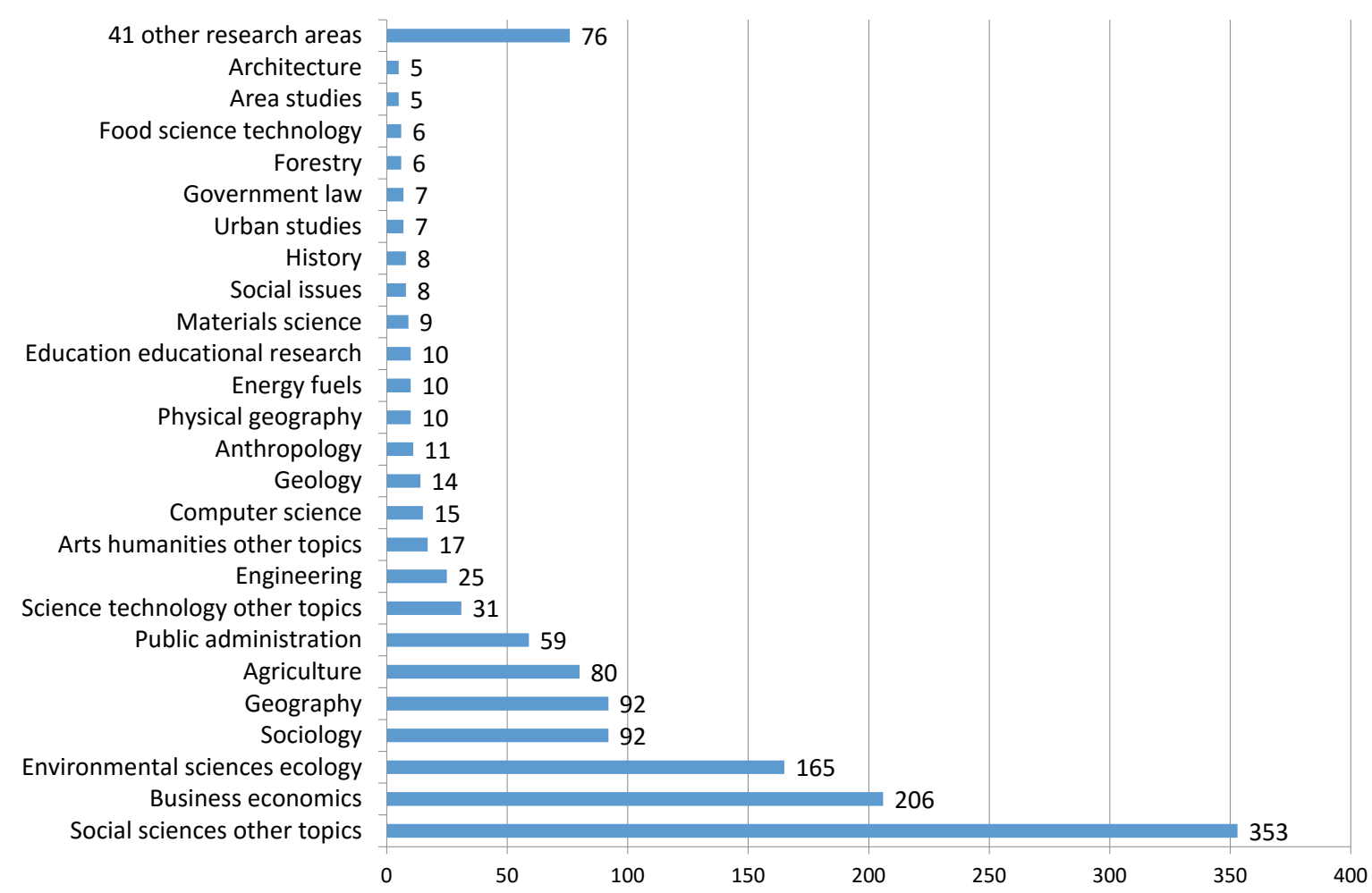

Figure 3: Records in WOS database retrievable with research areas and all terms, until the end of 2015

Slika 3: Zapisi v zbirki WOS, ki so najdljivi s klasifikacijo 'research areas' in vsemi pojmi, do konca leta 2015

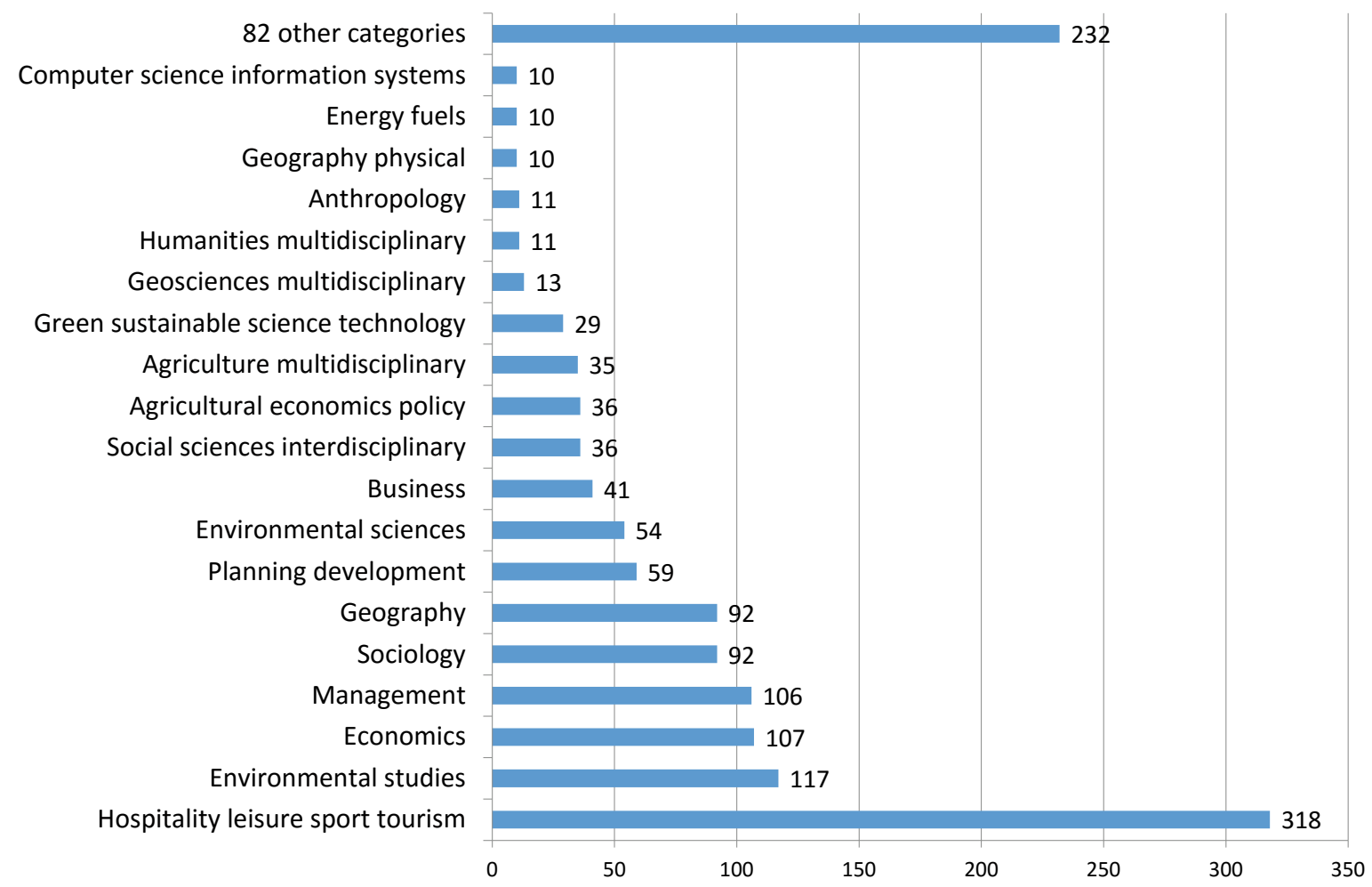

Figure 4: Records in WOS database retrievable with categories and all terms, until the end of 2015

Slika 4: Zapisi v zbirki WOS, ki so najdlivi s klasifikacijo 'categories' in vsemi pojmi, do konca leta 2015 
sometimes difficult to consistently identify publications on parallel principles, especially proceedings. These may involve problems caused by the use of different authoritynames and languages in either database so any analysis of this kind may entail some errors.

The top four Scopus journals in Table 2 are the same as the journals identified by (Ruhanen et al., 2015). They also figure among the six leading journals identified in Scopus by Lane and Kastenholz (2015), and among many of the top journals identified by Pato and Teixeira (2016) as dedicated principally to the rural entrepreneurship as connected with tourism. The journals Annals of Tourism Research, Journal of Travel Research, and Tourism Management were also assessed more generally by (Jiang et al., 2014) who found that these journals received more citations in Scopus than in WOS what is in fact in line

Table 2: Publication titles with at least ten rural-tourism-related paper titles in Scopus and WOS, until the end of 2015

Preglednica 2: Naslovi publikacij z vsaj desetimi prispevki na temo podeželskega turizma v zbirkah Scopus ter WOS, do konca 2015

\begin{tabular}{|c|c|c|}
\hline Journal/Proceedings/Book series & SCOPUS & WOS \\
\hline Tourism Management & 64 & 62 \\
\hline Journal of Sustainable Tourism & 39 & 21 \\
\hline Annals of Tourism Research & 34 & 36 \\
\hline Journal of Travel Research & 23 & 8 \\
\hline Current Issues in Tourism & 21 & 8 \\
\hline Wit Transactions on Ecology and the Environment & 19 & - \\
\hline International Journal of Tourism Research & 18 & 17 \\
\hline Tourism Geographies & 17 & 13 \\
\hline Tourism Planning and Development & 17 & - \\
\hline Tourism Economics & 14 & 8 \\
\hline Tourismos & 14 & - \\
\hline Quality Access to Success & 14 & - \\
\hline Worldwide Hospitality and Tourism Themes & 14 & - \\
\hline Scandinavian Journal of Hospitality and Tourism & 12 & 12 \\
\hline Advanced Materials Research & 12 & 7 \\
\hline Journal of Extension & 12 & - \\
\hline Journal of Rural Studies & 11 & 13 \\
\hline Journal of Travel and Tourism Marketing & 10 & 9 \\
\hline Actual Problems of Economics & 10 & 2 \\
\hline Tourism Management Perspectives & 10 & - \\
\hline Sociologia Ruralis & 5 & 12 \\
\hline Contemporary Geo. Leisure Tourism and Mobility & - & 14 \\
\hline Tourism and Agric. New Geog. ... Restructuring & - & 14 \\
\hline Procedia Social and Behavioral Sciences & - & 12 \\
\hline Medunarodni ... Istocne Hrvatske Jucer Danas Sutra & - & 10 \\
\hline
\end{tabular}

with a higher general coverage of journals by Scopus, especially for the social sciences.

Again, the differences between both databases notwithstanding, the weak interdisciplinarity or 'publishing inbreeding' is even more obvious when the more particular publishing practices are assessed, such as a choice of publication. The bulk of rural-tourism-related articles gets published in social sciences. Moreover, the most pronounced concentration of such documents can be attributed only to the most important tourism-related journals which have thus frequently been tackled also in scientometric research as evidenced by above-mentioned authors. This is in fact already evident in the WOS categories in Figure 4. Here it is interesting that the applicable WOS category of Hospitality leisure sport tourism is in the broader categorization scheme mapped indistinctly to Social sciences other topics. This interpretative finding points to an even further specialization which exacerbates integrative explanation of 'rural tourism' as a rural-agricultural as well as touristic phenomenon.

Table 3 further provides an information also for those top publications (at least five documents per publication in either database) which have been mapped to the category Agricultural and Biological Sciences in Scopus and to all applicable agricultural categories in WOS (according to WOS-to-OECD mapping, Frascati fields of science). Altogether, there were 145 documents published in 70 different publications in Scopus. In WOS, 91 such documents were published in 56 publications. In Scopus, this category is broader than in WOS as it also includes biological sciences. At this point it is worth noting the Journal of Rural Studies which appears in Scopus but not in WOS in Table 3 although this journal is obviously also indexed by WOS (Table 2). This journal which possesses clear agricultural/rural features already in its title is in WOS apparently not perceived as such. It is classified as Planning Development and Public Administration. Another example of the partiality of such classifications is the journal Sociologia Ruralis which is missed, in the sense of being agriculture-related, in both databases.

At this point we can at least men- 
tion that the dispersal of publications as well as database categories show very clear patterns of inverse relationship between the frequency and rank, or power laws, which can be evaluated in view of the so-called Bradford's law of scattering. Thus, an important part of relevant documents can be attributed to only a few items (publications as well as categories) whereas many documents appear only in one single publication title and respective category. This dimension, however, was not a topic of this research and remains to be investigated in some further study.

We can conclude that a weak interest in this phenomenon in agricultural publications (also noted by Lane and Kastenholz, 2015) represents a loss for agricultural sciences which have apparently not seized as yet an opportunity to integrate the outcomes from social sciences. This analysis was based only on published documents. A more complex assessment of interdisciplinarity would need to include both the documents as well as references in these documents in the sense of citing articles vs. cited articles (Stopar et al., 2016). This remains an objective for further research in this field.

As we have indicated before, there also exists a possibility that with further specialization within this research topic, genuine interdisciplinary will continue to decrease rather than increase, which can in a sense represent a further challenge for agricultural sciences. To assist and thus encourage truly interdisciplinary-minded researchers, publishers should broaden disciplinary descriptions of their journals, and other applicable publications, and become more inclusive for documents which transcend different conceptual and methodological traditions. By extension, this also applies to database managers.

Table 3: Publication titles with at least five rural-tourism-related paper titles as mapped to agricultural categories in Scopus and WOS, until the end of 2015 Preglednica 3: Naslovi publikacij z vsaj petimi prispevki na temo podeželskega turizma, ki so bile klasificirane s kmetijskimi kategorijami $v$ zbirkah Scopus ter WOS, do konca 2015

\begin{tabular}{lll}
\hline Journal/Proceedings/Book series & SCOPUS & WOS \\
\hline Journal of Rural Studies & 11 & - \\
Cuadernos de Desarrollo Rural & 6 & 7 \\
Berichte Uber Landwirtschaft & - & 7 \\
Journal of Agricultural Economics & 2 & 5 \\
Journal of Central European Agriculture & 6 & - \\
Advance Journal Of Food Science and Technology & 5 & - \\
Agricultural Economics & 5 & 2 \\
Journal of Food Agriculture and Environment & 5 & 4 \\
Journal of Agricultural and Resource Economics & 3 & 5 \\
\hline
\end{tabular}

\section{CONCLUSIONS}

The article deals with sociological and scientometric implications of information retrieval and subsequent inclusiveness of the research topic of rural tourism in two citation databases Scopus and WOS. We began on the premise of broadly accepted findings that the productivist role of the countryside, where agricultural production plays a key role, is increasingly leaning towards consumption and services, both in terms of land use as well as human resources. Namely, significance of non-agricultural activities in rural areas is steadily increasing. Consequently, agricultural production is no longer necessarily linked to socio-economic issues of the countryside. In the case of rural tourism, we presumed that this should also be reflected in scientific research and respective presentation of outcomes in publications across different research fields and scientific disciplines. In an explorative interpretative way we sought to assess the extent of this research topic as reflected in both citation databases up until the end of 2015. It should be noted that the concept of rural tourism and its possible impact on agriculture is interpreted differently in different socio-cultural milieus. Here, the awareness of social, cultural and linguistic particularities plays a substantial role. This is also reflected in (and has consequences for) subsequent information retrieval (conditioned by appropriate choice of search terms and construction of queries/search syntax) and interpretation of search results. Thus, we also discussed different (dis)functionalities of databases which can have an effect on information retrieval by end-users (researchers) as well as evaluation of research outcomes by information sciences, and, subsequently, national research evaluation in a more general sense. As assumed, and also substantiated by other authors, the documents are growing constantly. Even though we expected that the major part of research would be conducted within the frame of social sciences the almost exclusive prevalence thereof is nonetheless surprising. Roughly, some $90 \%$ of all documents are published in the more general frame of social sciences - if we also include economics and related topics. This is similarly reflected in database classifications - in both databases under study, where agricultural sciences are very rarely involved. Moreover, there is also a considerable concentration within the social sciences with most articles being published only in tourism-related journals. Strong congregation of publishing in a very specialized field of tourism is perhaps also an indicator of 
weak working interdisciplinarity in the research field itself. The complexity and differentiation of the studied topic has been steadily increasing as has its commercial importance in many economies but how strongly are the researchers, in all applicable fields of science, aware of this? Seemingly, they prefer to publish in a restricted and 'safe' area of verified choice-journals.

Poor presence of this topic in agricultural research can be to some extent attributed to the interpretative nature of research approaches in social sciences which are not easily accepted in more life-sciences-oriented agricultural journals. However, the absence of this topic in such journals is nevertheless conspicuous and points to weak awareness of social changes in agricultural research which can, in a long-term, lead to agriculture losing out in many relevant promising research niches in the future.

\section{REFERENCES}

Almstedt, A. (2013). Post-productivism in rural areas: A contested concept. In L. Lundmark \& C. Sandström (Eds.), Natural resources and regional development theory (pp. 8-22). Umea: Institutionen for geografi och ekonomisk historia.

Bartol, T., Budimir, G., Dekleva-Smrekar, D., Pušnik, M., \& Južnič, P. (2014). Assessment of research fields in Scopus and Web of Science in the view of national research evaluation in Slovenia. Scientometrics, 98(2), 1491-1504. doi:10.1007/s11192-013-1148-8

Bartol, T., \& Hočevar, M. (2011). Topics related to social sciences by authors from Slovenia in agriculture-and-life-sciences database CAB Abstracts. Acta agriculturae Slovenica, 97(3), 197-205. doi:10.2478/v10014-011-0014-8

Bartol, T., \& Mackiewicz-Talarczyk, M. (2015). Bibliometric Analysis of Publishing Trends in Fiber Crops in Google Scholar, Scopus, and Web of Science. Journal of Natural Fibers, 12(6), 531-541. doi:10.1080/15440478.2014.972000

Bojnec, Š. (2010). Rural Tourism, Rural Economy Diversification, and Sustainable Development. Academica TuristicaTourism and Innovation Journal, 3(1-2), 7-15.

Crouch, G. I., \& Perdue, R. R. (2015). The Disciplinary Foundations of Tourism Research 1980-2010. Journal of Travel Research, 54(5), 563-577. doi:10.1177/0047287514559036

De Looze, M.-A., Coronini, R., Legentil, M., Jeannin, P., \& Magri, M.-H. (1996). Determining the core of journals of a research centre: The example of researchers from the Department of Rural Economy and Sociology of the Institut National de la Recherche Agronomique, France. Scientometrics, 36(2), 167-183. doi:10.1007/BF02017312

Fijo-León, M. I., \& Fuentes-Luque, A. (2013). A corpus-based approach to the compilation, analysis, and translation of rural tourism terms. Meta: Journal des traducteurs / Meta: Translators' Journal, 58(1), 212-226. doi:10.7202/1023817ar

Friedland, W. H. (2002). Agriculture and rurality: beginning the "final separation"? Rural sociology, 67(3), 350-371. doi:10.1111/j.1549-0831.2002.tb00108.x
Gómez-Núñez, A. J., Batagelj, V., Vargas-Quesada, B., MoyaAnegón, F., \& Chinchilla-Rodríguez, Z. (2014). Optimizing SCImago Journal \& Country Rank classification by community detection. Journal of Informetrics, 8(2), 369-383. doi:10.1016/j.joi.2014.01.011

Hall, C. M. (2011). Publish and perish? Bibliometric analysis, journal ranking and the assessment of research quality in tourism. Tourism Management, 32(1), 16-27. doi:10.1016/j. tourman.2010.07.001

Hassan, S.-U., Haddawy, P., \& Zhu, J. (2014). A bibliometric study of the world's research activity in sustainable development and its sub-areas using scientific literature. Scientometrics, 99(2), 549-579. doi:10.1007/s11192-013-1193-3

Hill, B. (2005). The new rural economy: change, dynamism and government policy. London: The Institute of Economic affairs.

Hočevar, M. (2012). Dispersed settlement in detached houses: Attitudes over the residential space consumption in Slovenia. Sociologija, 54(1), 123-152. doi:10.2298/SOC1201123H

Jiang, J., Woosnam, K. M., \& Draper, J. (2014). Structural elements of articles and diachronous citation analysis among top-ranking tourism journals (1990-2010). Tourism Management Perspectives, 12, 48-56. doi:10.1016/j. tmp.2014.06.004

Lane, B., \& Kastenholz, E. (2015). Rural tourism: the evolution of practice and research approaches - towards a new generation concept? Journal of Sustainable Tourism, 23(8-9), 1133-1156. doi:10.1080/09669582.2015.1083997

Law, R., Ye, Q., Chen, W., \& Leung, R. (2009). An Analysis of the Most Influential Articles Published in Tourism Journals from 2000 to 2007: A Google Scholar Approach. Journal of Travel \& Tourism Marketing, 26(7), 735-746. doi:10.1080/10548400903284628

Lélé, S., \& Norgaard, R. B. (2005). Practicing interdisciplinarity. BioScience, 55(11), 967-975. doi:10.1641/00063568(2005)055[0967:PI]2.0.CO;2

Mackay, M., Perkins, H. C., \& Espiner, S. (2009). The study of rural change from a social scientific perspective: a literature review and annotated bibliography. Lincoln: Lincoln University. Department of Social Science, Parks, Recreation, Tourism and Sport.

Manca, E. (2008). From phraseology to culture Qualifying adjectives in the language of tourism. International Journal of Corpus Linguistics, 13(3), 368-385. doi:10.1075/ ijcl.13.3.07man

Mastronardi, L., Giaccio, V., Giannelli, A., \& Scardera, A. (2015). Is agritourism eco-friendly? A comparison between agritourisms and other farms in Italy using farm accountancy data network dataset. SpringerPlus, 4(590). doi:10.1186/s40064-015-1353-4

Mavri, R., \& Černič-Istenič, M. (2014). Podeželski turizem in socialni kapital v Sloveniji (primer vasi v Občini Cerkno) [Rural tourism and social capital in Slovenia (an example of villages in the Municipality of Cerkno)]. Geografski vestnik, 86(1), 51-61. doi:10.3986/GV86104

Moon, J., Hossain, M. D., Kang, H. G., \& Shin, J. (2012). An analysis of agricultural informatization in Korea: the government's role in bridging the digital gap. Information Development, 28(2), 102-116. doi:10.1177/0266666911432959 
Nielsen, N. C., Nissen, K. A., \& Just, F. (2010). Rural tourismreturn to the farm perspective. In 19th Nordic Symposium in Tourism and Hospitality Research.

Nuijten, E. (2011). Combining research styles of the natural and social sciences in agricultural research. NJAS-Wageningen Journal of Life Sciences, 57(3), 197-205. doi:10.1016/j. njas.2010.10.003

Pato, M. L., \& Teixeira, A. A. C. (2016). Twenty Years of Rural Entrepreneurship: A Bibliometric Survey. Sociologia Ruralis, 56(1), 3-28. doi:10.1111/soru.12058

Phillip, S., Hunter, C., \& Blackstock, K. (2010). A typology for defining agritourism. Tourism Management, 31(6), 754758. doi:10.1016/j.tourman.2009.08.001

Ruhanen, L., Weiler, B., Moyle, B. D., \& McLennan, C. J. (2015). Trends and patterns in sustainable tourism research: a 25 year bibliometric analysis. Journal of Sustainable Tourism, 23(4), 517-535. doi:10.1080/09669582.2014.978790

Schroeder, R., Zimmermann, F., \& Formiga, N. (2016). Growing Complexity in Rural Areas. Networking through Tourism and Recreation. American Journal of Rural Development, 4(1), 15-23.

Stopar, K., Drobne, D., Eler, K., \& Bartol, T. (2016). Citation analysis and mapping of nanoscience and nanotechnology: identifying the scope and interdisciplinarity of research.
Scientometrics, 106(2), 563-581. doi:10.1007/s11192-0151797-x

Tian, Y. E., Lee, H. A., \& Law, R. (2011). A comparison of research topics in leading tourism journals. International Journal of Tourism Sciences, 11(3), 108-126. doi:10.1080/15 980634.2011.11434649

Uršič, M., \& Hočevar, M. (2007). Protiurbanost kot nacin zivljenja [Anti-urbanity as a way of life]. Ljubljana: Univerza v Ljubljani, Fakulteta za druzbene vede.

Van der Ploeg, J. D., Renting, H., Brunori, G., Knickel, K., Mannion, J., Marsden, T., et al. (2000). Rural development: from practices and policies towards theory. Sociologia ruralis, 40(4), 391-408. doi:10.1111/1467-9523.00156

Wilson, G. A. (2007). Multifunctional agriculture: a transition theory perspective. Wallingford: CABI. doi:10.1079/9781845932565.0000

Wu, B., Xiao, H., Dong, X., Wang, M., \& Xue, L. (2012). Tourism Knowledge Domains: A Keyword Analysis. Asia Pacific Journal of Tourism Research, 17(4), 355-380. doi:10.1080/1 0941665.2011.628330

Yozukmaz, N., Akinci-Ekiztepe, B., \& Çeken, H. (2014). The Importance of Rural Tourism: Rural Tourism Practices in the World and in Turkey. Uluslararası Sosyal ve Ekonomik Bilimler Dergisi / International Journal of Social and Economic Sciences, 4(2), 37-44. 